Braz J Med Biol Res, September 2011, Volume 44(9) 933-938

doi: 10.1590/S0100-879X2011007500103

Hypertensive effects of the iv administration of picomoles of ouabain

A.S. Padilha, M. Salaices, D.V. Vassallo, P.R. Batista and F.D.M. Siman

The Brazilian Journal of Medical and Biological Research is partially financed by

\section{惡CNPq}

da Ciência e Tecnologia

Institutional Sponsors
DFAPESP
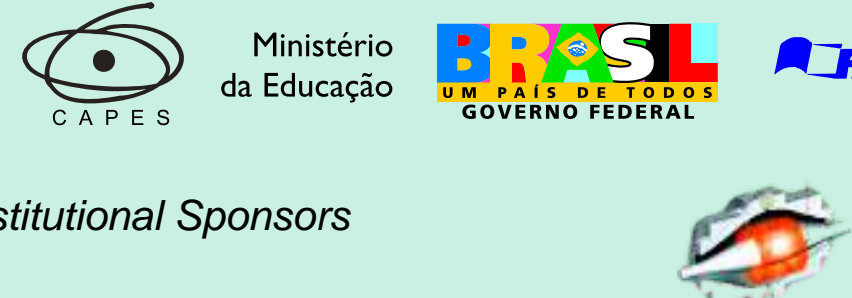

$\sin \theta_{0}$
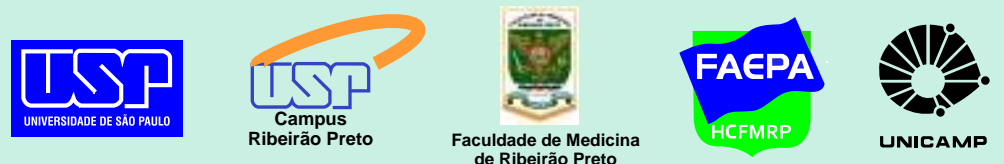

Ф SHIMADZU

Explore High - Performance MS Orbitrap Technology

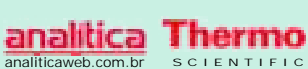




\title{
Hypertensive effects of the iv administration of picomoles of ouabain
}

\author{
A.S. Padilha1 ${ }^{1}$, M. Salaices ${ }^{2}$, D.V. Vassallo ${ }^{1,3}$, P.R. Batista ${ }^{1}$ and F.D.M. Siman ${ }^{1}$ \\ ${ }^{1}$ Departamento de Ciências Fisiológicas, Universidade Federal do Espírito Santo, Vitória, ES, Brasil \\ 2Departamento de Farmacología y Terapéutica, Facultad de Medicina, Universidad Autónoma Madrid, MD, Spain \\ ${ }^{3}$ Departamento de Ciências Fisiológicas, Escola Superior de Ciências da Santa Casa de Misericórdia de Vitória, \\ Vitória, ES, Brasil
}

\begin{abstract}
Ouabain, an endogenous digitalis compound, has been detected in nanomolar concentrations in the plasma of several mammals and is associated with the development of hypertension. In addition, plasma ouabain is increased in several hypertension models, and the acute or chronic administration of ouabain increases blood pressure in rodents. These results suggest a possible association between ouabain and the genesis or development and maintenance of arterial hypertension. One explanation for this association is that ouabain binds to the $\alpha$-subunit of the $\mathrm{Na}^{+}$pump, inhibiting its activity. Inhibition of this pump increases intracellular $\mathrm{Na}^{+}$, which reduces the activity of the sarcolemmal $\mathrm{Na}^{+} / \mathrm{Ca}^{2+}$ exchanger and thereby reduces $\mathrm{Ca}^{2+}$ extrusion. Consequently, intracellular $\mathrm{Ca}^{2+}$ increases and is taken up by the sarcoplasmic reticulum, which, upon activation, releases more calcium and increases the vascular smooth muscle tone. In fact, acute treatment with ouabain enhances the vascular reactivity to vasopressor agents, increases the release of norepinephrine from the perivascular adrenergic nerve endings and promotes increases in the activity of endothelial angiotensin-converting enzyme and the local synthesis of angiotensin II in the tail vascular bed. Additionally, the hypertension induced by ouabain has been associated with central mechanisms that increase sympathetic tone, subsequent to the activation of the cerebral renin-angiotensin system. Thus, the association with peripheral mechanisms and central mechanisms, mainly involving the renin-angiotensin system, may contribute to the acute effects of ouabain-induced elevation of arterial blood pressure.
\end{abstract}

Key words: Ouabain; Hypertension; Vascular reactivity; Renin-angiotensin system

\section{Introduction}

Endogenous cardiac glycoside increases to nanomolar concentrations in the plasma of hypertensive humans and rats $(1,2)$; in patients with diabetes $(3)$, myocardial infarction (4), congestive heart failure (5) and other diseases, and after acute physical exercise (6). This substance was characterized as ouabain or as an isomer of ouabain (7) and is produced in the central nervous system $(8,9)$, the adrenal cortex (10), and the heart (11). Acute administration of ouabain promotes a positive inotropic effect (12) and increases blood pressure and the contraction of vascular smooth muscle $(13,14)$. These findings suggest that ouabain increases vascular resistance and induces hypertension (Figure 1).

In addition to its hypertensive effects, endogenous ouabain also modifies cardiac function and modulates cellular proliferation and differentiation in the heart (15) and vascular smooth muscle (16).
The primary site of ouabain action is generally assumed to be the $\alpha$-subunit of $\mathrm{Na}^{+}, \mathrm{K}^{+}$-ATPase, which is a heterotrimer composed of $\alpha-, \beta$ - and $\gamma^{-}$-subunits which exist as isoforms $(17,18)$. Ouabain inhibits $\mathrm{Na}^{+}, \mathrm{K}^{+}$-ATPase by binding mainly to the $\alpha_{2}$ and $\alpha_{3}$ isoforms of the $\alpha$-subunit of the enzyme in rodents $(13,19)$. This inhibition increases the $\mathrm{Na}^{+}$concentration in the cytoplasm, which reduces the activity of the $\mathrm{Na}^{+} / \mathrm{Ca}^{2+}$ exchanger (NCX) and consequently increases the amount of $\mathrm{Ca}^{2+}$ available to activate contraction in tissues such as the heart, producing a positive inotropic effect $(19,20)$. However, low concentrations of ouabain stimulate $\mathrm{Ca}^{2+}$ transients in arterial smooth muscle without raising cytosolic $\left(\mathrm{Na}^{+}\right)(21)$. This apparent contradiction can be explained by the co-localization of the $\alpha_{2}$ and $\alpha_{3}$ isoforms of $\mathrm{Na}^{+}, \mathrm{K}^{+}$-ATPase and the NCX, which increases $\mathrm{Na}^{+}$concentration only at the plasmerosome region in response to ouabain (19). The increase of $\mathrm{Na}^{+}$con-

Correspondence: A.S. Padilha, Departamento de Ciências Fisiológicas, CBM/UFES, Av. Marechal Campos, 1468, 29040-091 Vitória, ES, Brasil. Fax: +55-27-335-7330. E-mail: ale_padilha@hotmail.com

Presented at the XV Simpósio Brasileiro de Fisiologia Cardiovascular, São Paulo, SP, Brazil, February 2-5, 2011.

Received February 22, 2011. Accepted July 20, 2011. Available online August 19, 2011. Published September 16, 2011. 
centration in the plasmerosome region might reduce the activity of the NCX. As a result, intracellular calcium concentration increases, as do vascular tone and blood pressure $(19,21)$. This suggests that ouabain acts as a pressor agent.

Xie and Cai (22) propose that low doses of ouabain, which are insufficient to inhibit $\mathrm{Na}^{+}, \mathrm{K}^{+}$-ATPase activity, could bind the caveolar $\mathrm{Na}^{+}, \mathrm{K}^{+}$-ATPase and activate some protein and lipid kinase cascades, thus generating several secondary messengers that, in turn, might modify cellular function. Thus, ouabain may modulate cellular proliferation and differentiation in the heart (15) and vascular smooth muscle (16), which could contribute to the maintenance of hypertension.

Ouabain might increase blood pressure via different mechanisms on different tissues and systems. In this review, we shall focus on the acute effects of ouabain on vascular reactivity and the central nervous system, mechanisms which might contribute to the development of hypertension.

\section{Acute effects of picomole quantities of ouabain on vascular reactivity}

In normal human volunteers $(23)$ and rats $(14,24)$, shortterm iv administration of ouabain in the range of $10-30 \mathrm{nmol} /$ $\mathrm{kg}$ produces a pressor response that is peripheral in origin.
In addition, an iv subpressor dose of ouabain, $0.1 \mathrm{mg} / \mathrm{m}^{2}$, enhances the ability of a single dose of norepinephrine to increase mean arterial pressure (25). Indeed, low doses of ouabain (6 and $18 \mu \mathrm{g} / \mathrm{kg}$, which correspond to approximately 10 and $30 \mathrm{nmol} / \mathrm{kg}$ ) increase the vasoconstrictor response to phenylephrine (24).

In the reflex-blocked anesthetized rat, ouabain increases diastolic pressure by phentolamine-sensitive and -insensitive mechanisms $(26,27)$. At the doses used, ouabain induced increases in diastolic pressure but did not alter the doseresponse curve for phenylephrine or the responsiveness to submaximal doses of norepinephrine. Because reflexes were blocked, the authors concluded that the short-term pressor effects of ouabain are not related to its direct central nervous system actions. Moreover, the authors suggested that the pressor actions of ouabain are mediated by norepinephrine released from sympathetic nerves as well as by a direct action on vascular smooth muscle cells. Presumably, both actions are due to the inhibition of $\mathrm{Na}^{+}, \mathrm{K}^{+}$-ATPase. Thus, the role of endogenous ouabain in hypertension would also include the amplification of contractile responses.

In some rat models of hypertension, including the SHR model (28), renovascular hypertension and L-NAMEinduced hypertension (29), acute ouabain administration

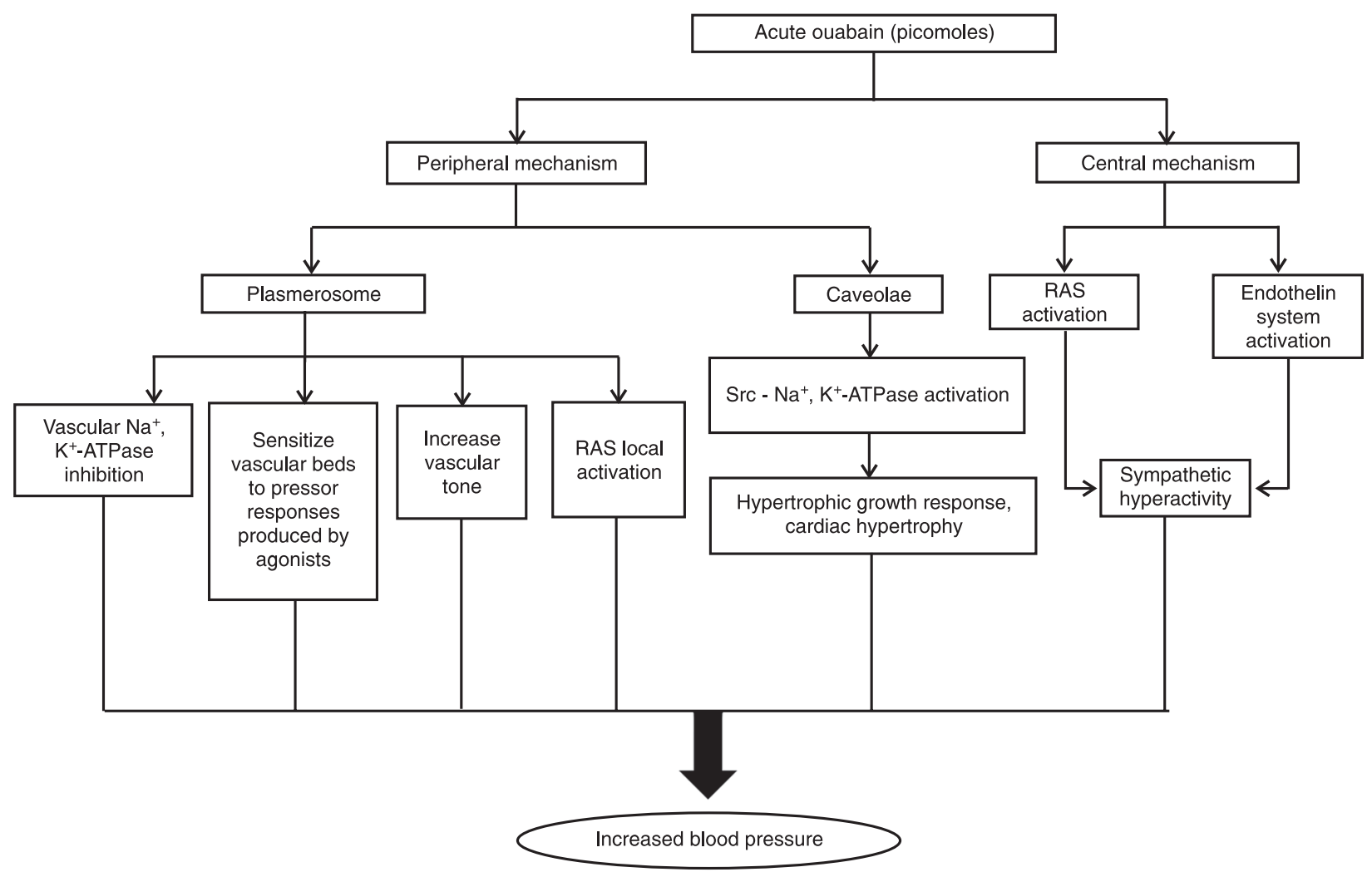

Figure 1. A generalized scheme showing the central and peripheral actions of acute ouabain. $\mathrm{RAS}=$ renin-angiotensin system; $\mathrm{Src}=$ sarcoma kinase. 
increases blood pressure, whereas no change in blood pressure is observed in normotensive rats $(14,30,31)$. These results suggest that the effects of ouabain are amplified in hypertensive conditions. We recently demonstrated in SHR that low picomole doses of ouabain (iv) increases systolic and diastolic blood pressure by a mechanism that seems to depend on activation of the renin-angiotensin system (31). However, because the effect of ouabain on diastolic blood pressure was not blocked by canrenone $(1 \mathrm{mg} / \mathrm{kg})$, we suggest that ouabain may have a mechanism of action that is independent of $\mathrm{Na}^{+}$pump inhibition.

Ouabain and a series of structurally related analogs have hypertensinogenic activity, regardless of their potency as $\mathrm{Na}^{+}$pump inhibitors (32). In addition, Ward et al. (33) suggested that adrenocortical cells express ouabain receptors that are distinct from the $\mathrm{Na}^{+}$pumps. These findings could explain why the pressor effect of ouabain on diastolic blood pressure seems not to depend on its effect on the $\mathrm{Na}^{+}$pump.

In the past few years, it has become apparent that binding of either endogenous or exogenous cardiotonic steroids, such as ouabain, to caveolar $\mathrm{Na}^{+}, \mathrm{K}^{+}$-ATPase evokes protein and lipid kinase cascades, thus generating several secondary messengers (22). This signaling pathway involves the association of protein tyrosine kinases (Src) with the $\mathrm{Na}^{+}, \mathrm{K}^{+}$-ATPase in a caveolar domain (34). Therefore, once the $\mathrm{Na}^{+}, \mathrm{K}^{+}$-ATPase/Src complex is activated by ouabain, Src is activated, initiating a cascade of signaling events. As a result, downstream effectors are activated, resulting in the activation of protein kinase cascades and the generation of second messengers. This leads to a cascade that involves the generation of reactive oxygen species (ROS), activation of extracellular signal-regulated protein kinase (ERK) through activation of its mitogen-activated protein kinase (MEK), activation of phosphatidylinositol 3-kinase (PI3K), stimulation of endocytosis and activation of Akt, as well as activation of protein kinase $C(22,34,35)$. This binding of ouabain to $\mathrm{Na}^{+}, \mathrm{K}^{+}$-ATPase affects multiple cellular functions, thereby influencing cell growth, heart hypertrophy and apoptosis (22).

Ouabain can act directly on the vasculature to increase vascular resistance or to sensitize vascular beds to pressor responses produced by norepinephrine, angiotensin II, and phenylephrine (28,36-40). In vitro, picomole doses of ouabain enhance caffeine-induced contractures and increase the ability of phenylephrine to potentiate caffeine-induced contractions of rat isolated vascular preparations (41). These observations support the hypothesis that picomole quantities of ouabain should selectively interact with the high-affinity $\alpha_{2}$ and $\alpha_{3}$ isoforms of $\mathrm{Na}^{+}, \mathrm{K}^{+}$-ATPase to enhance the actions of vasoconstrictor agents.

Endothelium-derived factors might positively or negatively modulate the vascular actions of ouabain. Thus, the endothelium modulates the actions of picomole quantities of acutely administered ouabain in vascular preparations from normotensive and hypertensive rats $(28,29,40)$.

In the tail vascular bed from normotensive Wistar rats, Rossoni et al. (40) demonstrated that the acute perfusion of ouabain $(10 \mathrm{nM})$ induces the release of a potassium channel opener and that the effects of ouabain are partially modulated by the endothelium. On the other hand, in cultured rat aortic endothelial cells, ouabain (10 nM) contributes to the bradykinin-stimulated increase of nitric oxide (NO) production by inhibiting plasma membrane $\mathrm{Na}^{+}, \mathrm{K}^{+}$-ATPase activity and increasing intracellular $\mathrm{Na}^{+}$ concentration (42). Moreover, Eva et al. (43) demonstrated that small quantities of ouabain stimulate NO production in human umbilical artery endothelial cells via PI3K. The binding of ouabain to $\mathrm{Na}^{+}, \mathrm{K}^{+}$-ATPase initiates a signal via $\mathrm{PI} 3 \mathrm{~K}$, which turns on the proliferation and survival pathways that involve Akt and that stimulate endogenous nitric oxide synthase (eNOS) and NO production (43). Because NO is an endothelial factor that activates $\mathrm{Na}^{+}, \mathrm{K}^{+}$-ATPase (44), we speculated that picomole quantities of ouabain could release $\mathrm{NO}$, which, in turn, could stimulate $\mathrm{Na}^{+}, \mathrm{K}^{+}$-ATPase activity, reducing vascular reactivity in normotensive rats. In L-NAME-hypertensive rats, the acute administration of ouabain $(10 \mathrm{nM})$ induces the release of endothelium-derived hyperpolarizing factor in the tail vascular bed (29). This and other results support the notion that the endothelium might modulate the action of acute and chronic ouabain administration $(28,29,40,45)$.

In the aorta from SHR, ouabain at micromolar concentrations releases an unknown vasoconstrictor factor not related to products from the arachidonic acid pathway or free radical release (39). However, the perfusion with a lower concentration of ouabain $(1 \mathrm{nM})$ increases the sensitivity to phenylephrine in the tail vascular bed of SHR by a mechanism involving increased activity of endothelial angiotensin-converting enzyme and the local synthesis of angiotensin II (28). Indeed, the role of low-concentration ouabain (10 $\mathrm{nM})$ in the local renin-angiotensin system was demonstrated in bovine adrenal glomerulosa cells (46). In that report, the authors showed that ouabain interacts with angiotensin II to stimulate aldosterone production in bovine adrenal glomerulosa cells. On the other hand, the central mechanism described above suggests that ouabain stimulates the brain renin-angiotensin system, leading to the production of angiotensin II, which further increases sympathetic tone and ultimately increases arterial blood pressure (47). We also found that the increases in systolic and diastolic blood pressure induced by low-dose ouabain $(\sim 0.3 \mathrm{nmol} / \mathrm{kg}$ ) were blocked completely by pretreatment (iv) with $10 \mathrm{mg} / \mathrm{kg}$ losartan, although these increases were not affected by ganglionic blockade with $5 \mathrm{mg} / \mathrm{kg}$ hexamethonium, suggesting that ouabain, at least at this concentration, does not act on preganglionic neurons $(28,31)$. On the other hand, the increase of blood pressure induced by $0.18 \mu \mathrm{g} / \mathrm{kg}$ ouabain in L-NAME-hypertensive rats is blocked by hexamethonium (29). Taken together, these 
observations indicate that in SHR, ouabain activates the local renin-angiotensin system, which induces increases in vascular resistance and blood pressure. The classical effect of ouabain is the inhibition of $\mathrm{Na}^{+}, \mathrm{K}^{+}$-ATPase activity by binding mainly to the $\alpha_{2}$ and $\alpha_{3}$ isoforms of the $\alpha$-subunit of the enzyme in rodents $(13,19)$. Indeed, we demonstrated that in SHR, $1 \mathrm{nM}$ ouabain activates rather than inhibits $\mathrm{Na}^{+}, \mathrm{K}^{+}$-ATPase activity in vascular smooth muscle (28), an observation similar to that described by Gao et al. (48) in cardiac myocytes. However, the angiotensin II released by the action of ouabain may also be able to stimulate $\mathrm{Na}^{+}, \mathrm{K}^{+}$-ATPase activity (49).

Although the peripheral actions of ouabain could contribute to increased blood pressure, the central mechanisms, already well established, are also important mediators of increased pressure induced by this digitalis. Therefore, the central mechanism of ouabain is described below.

\section{Acute effects of ouabain on the central nervous system}

The effects of ouabain on the central nervous system have been well established. Neurons express the $\alpha_{3}$ isoform of $\mathrm{Na}^{+} / \mathrm{K}^{+}$-ATPase, the most ouabain-sensitive isoform of the $\alpha$-subunits, and therefore neurons are very sensitive to the effects of this substance.

Indeed, the acute administration of ouabain in some regions of the central nervous system, such as the median preoptic nucleus (50), paraventricular nucleus (51) or rostral ventrolateral medulla (52), causes dose-dependent increases in sympathetic nerve activity, blood pressure and heart rate. Therefore, these findings suggest that endogenous ouabain might be a regulator of sympathetic tone and arterial blood pressure by influencing some areas of cardiovascular pressor control. This hypothesis seems to be confirmed by reports that the sympathoexcitatory and pressor effects induced by ouabain can be reversed and prevented by the intracerebroventricular administration of antibody Fab fragments, which bind ouabain, blocking its actions $(9,53)$. The sympathetic hyperactivity induced by ouabain and the consequent increase in blood pressure appear to involve the central renin-angiotensin system. This observation is supported by reports that the sympathetic hyperactivity induced by ouabain is prevented by an AT1 receptor blocker (50-52), suggesting that the central renin-angiotensin system could be the sympathoexcitatory component involved in the hypertensinogenic effect of ouabain. In addition, the acute hypertensinogenic effect of ouabain is attenuated in transgenic rats that are deficient in brain angiotensinogen (54). Therefore, in some diseases that are accompanied by an increased level of endogenous ouabain, such as hypertension (1), heart failure (55) and diabetes (35), the increase in sympathoexcitatory activity could be due to the actions of ouabain on the central reninangiotensin system. In addition to the sympathoexcitatory activity induced by ouabain via the central renin-angiotensinaldosterone pathway, D'Amico at al. (56) demonstrated that the central endothelin system (periaqueductal gray area) of rats is also involved in this sympathetic activation and in the ouabain-induced hemodynamic effects.

Ouabain release in the brain is very sensitive to sodium loading (9). This position is supported by the observation that the effects of sodium loading can be mimicked by intrahippocampal microinjection of ouabain (57). Indeed, acute intrahippocampal administration of an extremely low dose of ouabain (60 pg) in Dahl salt-sensitive rats (DSS) is associated with activation of the renin-angiotensin-aldosterone system in the hypothalamus and adrenal cortex, an increase in the adrenocortical level of marinobufagenin, inhibition of sodium pumps in the vasculature and kidney, and pressor and natriuretic responses (57). Moreover, the central administration of $\mathrm{NaCl}$ or $\mathrm{NaCl}$ loading in DSS or SHR rats induces increases in brain endogenous ouabain that, in turn, induce sympathoactivation and increase blood pressure $(9,53)$. However, the evidence regarding the relationship between $\mathrm{NaCl}$ loading and increased ouabain level is contradictory. Manunta et al. (58) demonstrated in healthy humans that $\mathrm{NaCl}$ depletion produced an elevation in the plasma concentration of endogenous ouabain, but in the same study, 3 days of $\mathrm{NaCl}$ loading (171 mEq NaCl/day) caused a transient elevation in the plasma concentration of endogenous ouabain. In another report (59), acute $\mathrm{NaCl}$ loading in DSS and Dahl salt-resistant (DR) rats caused a transient increase in an ouabain-like compound in the pituitary gland, adrenal gland, and plasma, followed by a decrease to baseline. Therefore, it seems that the plasma level of endogenous ouabain may not be a good indicator of volume expansion because it displays transient response.

\section{General considerations}

Endogenous ouabain was discovered in humans 20 years ago, and its effects on sodium pumps have been widely explored, although much remains to be clarified. In general, endogenous ouabain participates in the control of blood pressure and sodium balance (1), but it also modifies cardiac function and modulates cellular proliferation and differentiation of the heart (15) and vascular smooth muscle (16).

Acutely, ouabain in picomole quantities increases blood pressure (24,28-31), pressor and vascular reactivity to vasoconstrictor agents $(14,24,28-31,40,41)$, and sympathoexcitatory activity $(9,53)$. These effects of ouabain are due at least in part to activation of the central and peripheral renin-angiotensin system $(31,28,50-52)$.

Understanding the mechanisms of the effects of acute ouabain on the cardiovascular system is important because acute conditions of $\mathrm{NaCl}$ loading (13,57-59) or physical exercise (6) induce a sudden increase in the plasma level of endogenous ouabain. In some diseases, such as 
hypertension $(1,2)$, diabetes (3), myocardial infarction (4), and congestive heart failure (5), the basal plasma level of ouabain is increased. Therefore, acute conditions that elevate ouabain should be evaluated and studied to verify the systemic repercussions.

\section{References}

1. Hamlyn JM, Hamilton BP, Manunta P. Endogenous ouabain, sodium balance and blood pressure: a review and a hypothesis. J Hypertens 1996; 14: 151-167.

2. Pamnani M, Huot S, Buggy J, Clough D, Haddy F. Demonstration of a humoral inhibitor of the $\mathrm{Na}^{+}-\mathrm{K}^{+}$pump in some models of experimental hypertension. Hypertension 1981; 3: II-96-II-101.

3. Bagrov YY, Manusova NB, Egorova IA, Fedorova OV, Bagrov AY. Endogenous digitalis-like ligands and $\mathrm{Na} / \mathrm{K}$ ATPase inhibition in experimental diabetes mellitus. Front Biosci 2005; 10: 2257-2262.

4. Bagrov AY, Fedorova OV, Maslova MN, Roukoyatkina NI, Ukhanova MV, Zhabko EP. Endogenous plasma Na,KATPase inhibitory activity and digoxin like immunoreactivity after acute myocardial infarction. Cardiovasc Res 1991; 25: 371-377.

5. Manunta P, Messaggio E, Casamassima N, Gatti G, Carpini $\mathrm{SD}$, Zagato L, et al. Endogenous ouabain in renal $\mathrm{Na}(+)$ handling and related diseases. Biochim Biophys Acta 2010; 1802: 1214-1218.

6. Bauer N, Muller-Ehmsen J, Kramer U, Hambarchian N, Zobel C, Schwinger RH, et al. Ouabain-like compound changes rapidly on physical exercise in humans and dogs: effects of beta-blockade and angiotensin-converting enzyme inhibition. Hypertension 2005; 45: 1024-1028.

7. Hamlyn JM, Blaustein MP, Bova S, DuCharme DW, Harris $\mathrm{DW}$, Mandel F, et al. Identification and characterization of a ouabain-like compound from human plasma. Proc Natl Acad Sci U S A 1991; 88: 6259-6263.

8. Songu-Mize E, Bealer SL, Caldwell RW. Effect of AV3V lesions on development of DOCA-salt hypertension and vascular $\mathrm{Na}^{+}$-pump activity. Hypertension 1982; 4: 575-580.

9. Huang BS, Leenen FH. Blockade of brain "ouabain" prevents sympathoexcitatory and pressor responses to high sodium in SHR. Am J Physiol 1996; 271: H103-H108.

10. Laredo J, Hamilton BP, Hamlyn JM. Ouabain is secreted by bovine adrenocortical cells. Endocrinology 1994; 135: 794797.

11. D'Urso G, Frascarelli S, Balzan S, Zucchi R, Montali U. Production of ouabain-like factor in normal and ischemic rat heart. J Cardiovasc Pharmacol 2004; 43: 657-662.

12. Cattell M, Gold $H$. The influence of digitalis glycosides on the force of contraction of mammalian cardiac muscle. $J$ Pharmacol Exp Ther 1938; 62: 116-125.

13. Blaustein MP. Physiological effects of endogenous ouabain: control of intracellular $\mathrm{Ca}^{2+}$ stores and cell responsiveness. Am J Physiol 1993; 264: C1367-C1387.

14. Vassallo DV, Songu-Mize E, Rossoni LV, Amaral SM. Effects of ouabain on vascular reactivity. Braz J Med Biol Res 1997; 30: $545-552$

15. Huang L, Li H, Xie Z. Ouabain-induced hypertrophy in cul-

\section{Acknowledgments}

Research supported by CNPq, CAPES, FAPES/ FUNCITEC (\#SAF2009 02376) and MCIIN (\#SAF2009 02376) and Banco Santader. tured cardiac myocytes is accompanied by changes in expression of several late response genes. $\mathrm{J} \mathrm{Mol} \mathrm{Cell} \mathrm{Cardiol}$ 1997; 29: 429-437.

16. Aydemir-Koksoy A, Abramowitz J, Allen JC. Ouabaininduced signaling and vascular smooth muscle cell proliferation. J Biol Chem 2001; 276: 46605-46611.

17. Shull GE, Greeb J, Lingrel JB. Molecular cloning of three distinct forms of the $\mathrm{Na}^{+}, \mathrm{K}^{+}$-ATPase alpha-subunit from rat brain. Biochemistry 1986; 25: 8125-8132.

18. Shamraj OI, Lingrel JB. A putative fourth $\mathrm{Na}^{+}, \mathrm{K}(+)$-ATPase alpha-subunit gene is expressed in testis. Proc Natl Acad Sci U S A 1994; 91: 12952-12956.

19. Blaustein MP, Juhaszova M, Golovina VA. The cellular mechanism of action of cardiotonic steroids: a new hypothesis. Clin Exp Hypertens 1998; 20: 691-703.

20. Blaustein MP. Sodium/calcium exchange and the control of contractility in cardiac muscle and vascular smooth muscle. J Cardiovasc Pharmacol 1988; 12 (Suppl 5): S56-S68.

21. Arnon A, Hamlyn JM, Blaustein MP. Ouabain augments $\mathrm{Ca}^{2+}$ transients in arterial smooth muscle without raising cytosolic $\mathrm{Na}^{+}$. Am J Physiol Heart Circ Physiol 2000; 279: H679-H691.

22. Xie Z, Cai T. $\mathrm{Na}^{+}-\mathrm{K}^{+}-\mathrm{ATP}$ ase-mediated signal transduction: from protein interaction to cellular function. Mol Interv 2003; 3: $157-168$

23. Mason DT, Braunwald DE. Studies on digitalis. X. Effects of ouabain on forearm vascular resistance and venous tone in normal subjects and in patients in heart failure. $J$ Clin Invest 1964; 43: 532-543.

24. Barker LA, Rossoni LV, Vassallo DV. Acute pressor actions of ouabain do not enhance the actions of phenylephrine or norepinephrine in anesthetized rats. J Cardiovasc Pharmacol 2001; 37: 339-348.

25. Yamaji I, Kikuchi K, Nishimura M, Nozawa A, Hasegawa T, Kobayakawa $\mathrm{H}$, et al. The role of $\mathrm{Na}$,K-ATPase inhibitor on pressor responsiveness in patients with benign essential hypertension. Am J Hypertens 1990; 3: 176-181.

26. Caldwell RW, Songu-Mize E, Bealer SL. The vasopressor response to centrally administered ouabain. Circ Res 1984; 55: 773-779.

27. Veerasingham SJ, Leenen FH. Ouabain- and central sodium-induced hypertension depend on the ventral anteroventral third ventricle region. Am J Physiol 1999; 276: H63-H70.

28. Padilha AS, Rossoni LV, Xavier FE, Vassallo DV. Ouabain at nanomolar concentration promotes synthesis and release of angiotensin II from the endothelium of the tail vascular bed of spontaneously hypertensive rats. J Cardiovasc Pharmacol 2004; 44: 372-380.

29. Rossoni LV, dos Santos L, Barker LA, Vassallo DV. Ouabain changes arterial blood pressure and vascular reactivity to 
phenylephrine in L-NAME-induced hypertension. J Cardiovasc Pharmacol 2003; 41: 105-116.

30. Rossoni LV, Pinto VD, Vassallo DV. Effects of small doses of ouabain on the arterial blood pressure of anesthetized hypertensive and normotensive rats. Braz J Med Biol Res 2001; 34: 1065-1077.

31. Siman FD, Stefanon I, Vassallo DV, Padilha AS. A low concentration of ouabain $(0.18 \mathrm{microg} / \mathrm{kg})$ enhances hypertension in spontaneously hypertensive rats by inhibiting the $\mathrm{Na}^{+}$ pump and activating the renin-angiotensin system. Braz $J$ Med Biol Res 2010; 43: 767-776.

32. Manunta P, Hamilton BP, Hamlyn JM. Structure-activity relationships for the hypertensinogenic activity of ouabain: role of the sugar and lactone ring. Hypertension 2001; 37: 472-477.

33. Ward SC, Hamilton BP, Hamlyn JM. Novel receptors for ouabain: studies in adrenocortical cells and membranes. Hypertension 2002; 39: 536-542.

34. Wang H, Haas M, Liang M, Cai T, Tian J, Li S, et al. Ouabain assembles signaling cascades through the caveolar $\mathrm{Na}^{+} /$ $\mathrm{K}^{+}$-ATPase. J Biol Chem 2004; 279: 17250-17259.

35. Bagrov AY, Shapiro JI, Fedorova OV. Endogenous cardiotonic steroids: physiology, pharmacology, and novel therapeutic targets. Pharmacol Rev 2009; 61: 9-38.

36. Marin J, Sanchez-Ferrer CF, Salaices M. Effects of ouabain on isolated cerebral and femoral arteries of the cat: a functional and biochemical study. Br J Pharmacol 1988; 93: 43-52.

37. Sanchez-Ferrer CF, Fernandez-Alfonso MS, Ponte A, Casado MA, Gonzalez R, Rodriguez-Manas L, et al. Endothelial modulation of the ouabain-induced contraction in human placental vessels. Circ Res 1992; 71: 943-950.

38. Songu-Mize E, Vassallo DV, Rashed SM, Varner KJ. Ouabain amplifies contractile responses to phenylephrine in rat tail arteries in hypertension. J Basic Clin Physiol Pharmacol 1995; 6: 309-319.

39. Ponte A, Sanchez-Ferrer CF, Hernandez C, Alonso MJ, Marin J. Effect of ageing and hypertension on endothelial modulation of ouabain-induced contraction and sodium pump activity in the rat aorta. J Hypertens 1996; 14: 705712.

40. Rossoni LV, Cunha V, Franca A, Vassallo DV. The influence of nanomolar ouabain on vascular pressor responses is modulated by the endothelium. J Cardiovasc Pharmacol 1999; 34: 887-892.

41. Weiss DN, Podberesky DJ, Heidrich J, Blaustein MP. Nanomolar ouabain augments caffeine-evoked contractions in rat arteries. Am J Physiol 1993; 265: C1443-C1448.

42. Dong $\mathrm{XH}$, Komiyama $\mathrm{Y}$, Nishimura N, Masuda M, Takahashi $\mathrm{H}$. Nanomolar level of ouabain increases intracellular calcium to produce nitric oxide in rat aortic endothelial cells. Clin Exp Pharmacol Physiol 2004; 31: 276-283.

43. Eva A, Kirch U, Scheiner-Bobis G. Signaling pathways involving the sodium pump stimulate $\mathrm{NO}$ production in endothelial cells. Biochim Biophys Acta 2006; 1758: 18091814.

44. Gupta S, Phipps K, Ruderman NB. Differential stimulation of
$\mathrm{Na}^{+}$pump activity by insulin and nitric oxide in rabbit aorta. Am J Physiol 1996; 270: H1287-H1293.

45. Rossoni LV, Salaices M, Miguel M, Briones AM, Barker LA, Vassallo DV, et al. Ouabain-induced hypertension is accompanied by increases in endothelial vasodilator factors. Am J Physiol Heart Circ Physiol 2002; 283: H2110-H2118.

46. Tamura M, Piston DW, Tani M, Naruse M, Landon EJ, Inagami T. Ouabain increases aldosterone release from bovine adrenal glomerulosa cells: role of renin-angiotensin system. Am J Physiol 1996; 270: E27-E35.

47. Huang BS, Leenen FH. Brain renin-angiotensin system and ouabain-induced sympathetic hyperactivity and hypertension in Wistar rats. Hypertension 1999; 34: 107-112.

48. Gao J, Wymore RS, Wang Y, Gaudette GR, Krukenkamp IB, Cohen IS, et al. Isoform-specific stimulation of cardiac $\mathrm{Na} / \mathrm{K}$ pumps by nanomolar concentrations of glycosides. J Gen Physiol 2002; 119: 297-312.

49. Simon G. Stimulation of vascular Na-K pump with subpressor angiotensin II in rats. Proc Soc Exp Biol Med 1992; 199: 424-431.

50. Budzikowski AS, Leenen FH. Brain 'ouabain' in the median preoptic nucleus mediates sodium-sensitive hypertension in spontaneously hypertensive rats. Hypertension 1997; 29: 599-605.

51. Gabor A, Leenen FH. Mechanisms in the PVN mediating local and central sodium-induced hypertension in Wistar rats. Am J Physiol Regul Integr Comp Physiol 2009; 296: R618-R630.

52. Teruya H, Yamazato M, Muratani H, Sakima A, Takishita S, Terano Y, et al. Role of ouabain-like compound in the rostral ventrolateral medulla in rats. J Clin Invest 1997; 99: 27912798.

53. Leenen FH, Harmsen E, Yu H. Dietary sodium and central vs. peripheral ouabain-like activity in Dahl salt-sensitive vs. salt-resistant rats. Am J Physiol 1994; 267: H1916-H1920.

54. Huang BS, Ganten D, Leenen FH. Responses to central $\mathrm{Na}^{+}$and ouabain are attenuated in transgenic rats deficient in brain angiotensinogen. Hypertension 2001; 37: 683-686.

55. Leenen FH, Huang BS, Yu H, Yuan B. Brain 'ouabain' mediates sympathetic hyperactivity in congestive heart failure. Circ Res 1995; 77: 993-1000.

56. D’Amico M, Di Filippo C, Piegari E, Rinaldi B, Rossi F, Filippelli A. ETA endothelin receptors are involved in the ouabaininduced haemodynamic effects in the periaqueductal gray area of rats. Life Sci 2003; 72: 2211-2218.

57. Fedorova OV, Zhuravin IA, Agalakova NI, Yamova LA, Talan MI, Lakatta EG, et al. Intrahippocampal microinjection of an exquisitely low dose of ouabain mimics $\mathrm{NaCl}$ loading and stimulates a bufadienolide Na/K-ATPase inhibitor. J Hypertens 2007; 25: 1834-1844.

58. Manunta P, Hamilton BP, Hamlyn JM. Salt intake and depletion increase circulating levels of endogenous ouabain in normal men. Am J Physiol Regul Integr Comp Physiol 2006; 290: R553-R559.

59. Fedorova OV, Lakatta EG, Bagrov AY. Endogenous Na,K pump ligands are differentially regulated during acute $\mathrm{NaCl}$ loading of Dahl rats. Circulation 2000; 102: 3009-3014. 